\title{
Regimen Used to Treat Malignant Peritoneal Neoplasm
}

National Cancer Institute

\section{Source}

National Cancer Institute. Regimen Used to Treat Malignant Peritoneal Neoplasm. NCI

Thesaurus. Code C159901.

Any regimen that can be used for the treatment of malignant peritoneal neoplasm. 